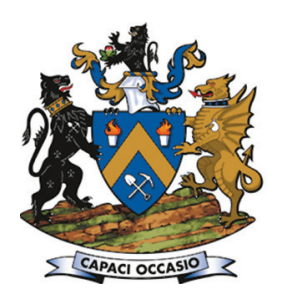

Affiliation:

1 Department of Earth Sciences, Stellenbosch University, Stellenbosch, South Africa.

2 Burgundy Mining Advisors Ltd.

Correspondence to:

B.P. von der Heyden

Email:

bvon@sun.ac.za

Dates:

Received: 8 Apr. 2020

Revised: 24 Jun. 2020

Accepted: 28 Aug. 2020

Published: September 2020

How to cite:

Leach, P., von der Heyden, B.P., and Ravenscroft, $P$.

A novel economic-filter for

evaluating sub-Saharan

diamondiferous kimberlites.

The Southern African Institute of

Mining and Metallurgy

DOI ID:

http://dx.doi.org/10.17159/24119717/1173/2020

ORCiD ID:

B.P. von der Heyden https://orchid.org/0000-00024006-9278

\section{A novel economic-filter for evaluating sub-Saharan diamondiferous kimberlites}

\author{
P. Leach' ${ }^{1}$, B.P. von der Heyden ${ }^{1}$, and P. Ravenscroft ${ }^{2}$
}

\begin{abstract}
Synopsis
Because of their high degree of geological complexity, kimberlite-hosted diamond deposits are exceedingly difficult to evaluate for economic viability. Accordingly, standard mineral asset evaluation protocols (e.g., the Cost-, Market-, and Income Approaches defined in the SAMREC Code) may not hold sufficient predictive abilities for these deposit types, especially at the early stages of exploration. Here we present a novel tool, a cost filter approach towards preliminary evaluation of economic viability of southern African kimberlite-hosted diamond deposits, using the AK6 and BK11 diamond deposits from the Orapa diamond field as case studies. The development of this cost filter is underpinned by elements of both the Market Approach (i.e., comparisons to similar deposits) and the Income Approach (i.e., use of net present value (NPV) calculations) for mineral asset evaluation. Importantly, the cost filter is constrained through modification of only two primary variables (the average diamond value and the diamond grade) and thus differs significantly from other cost filters that rely on estimation and assumptions for every parameter input into an NPV calculation. The cost filter correctly predicts the sub-economic status of the BK11 diamond pipe, and is thus presented as a useful geo-economic tool for early stage kimberlite evaluation within the local southern African context. The approach and its theoretical underpinning foreseeably hold vast potential for use in the economic evaluation of other ore commodities, particularly where socio-economic and political risk factors can be negated by employing a geographic constraint.
\end{abstract}

\section{Keywords}

diamond, economic viability, kimberlites, southern Africa, cost models filter.

\title{
Introduction
}

Sub-Saharan Africa has an established diamond resource industry which began with the first alluvial diamond discovery in the Gariep River (South Africa) in 1866, followed shortly thereafter by the discovery of the first kimberlitic diamond on the farm Koffiefontein and then the Jagersontein and Dutoitspan pipes near Kimberley, all in 1870 (Davenport, 2013). In the next 40 years, significant diamond deposits were discovered in Zimbabwe, Namibia, Angola, and the Belgian Congo (now the Democratic Republic of Congo); and later in Lesotho and Botswana in the 1950s and 1960s (McKechnie, 2019 and references therein). In more than 150 years of mining history, southern Africa has consistently been the dominant producer of the world's diamond supply (McKechnie, 2019), producing some of the world's largest and most famous stones, including the $3106 \mathrm{ct}$ Cullinan diamond (Cullinan Mine, South Africa, 1905), the 1109 ct Lesedi La Rona diamond (Karowe mine, Botswana, 2015), and the 972 ct Excelsior diamond (Jagersfontein Mine, South Africa, 1893). In the last two decades, southern Africa has continued to contribute vastly towards the world's total diamond output, both in terms of value and volume, producing around 40-50\% of global supply (Zimnisky, 2017; Kimberley Process Statistics 2004-2016), with the remainder produced predominantly by Russia, Australia, and Canada.

Despite both the historical and present day importance of southern African diamond supply, parts of the region are regarded as being mature mineral provinces with diminished exploration potential (e.g., South Africa), while other parts are hampered by various geopolitical risk factors (Campbell, 2019), and many of the region's tier-1 diamond operations are approaching the end of their production lifespans. Open pit operations at Orapa and Jwaneng are predicted to end in 2030 and 2035 respectively, while Venetia is in the process of moving from an open pit to underground operation (Table I). These local supply factors, compounded by the predicted 1-4\% annual increase in natural diamond demand (Linde et al., 2016), emphasize the need for continued exploration efforts to identify diamondiferous kimberlite pipes in sub-Saharan Africa that can be developed at lowered financial risk. To this end, the current 


\section{A novel economic-filter for evaluating sub-Saharan diamondiferous kimberlites}

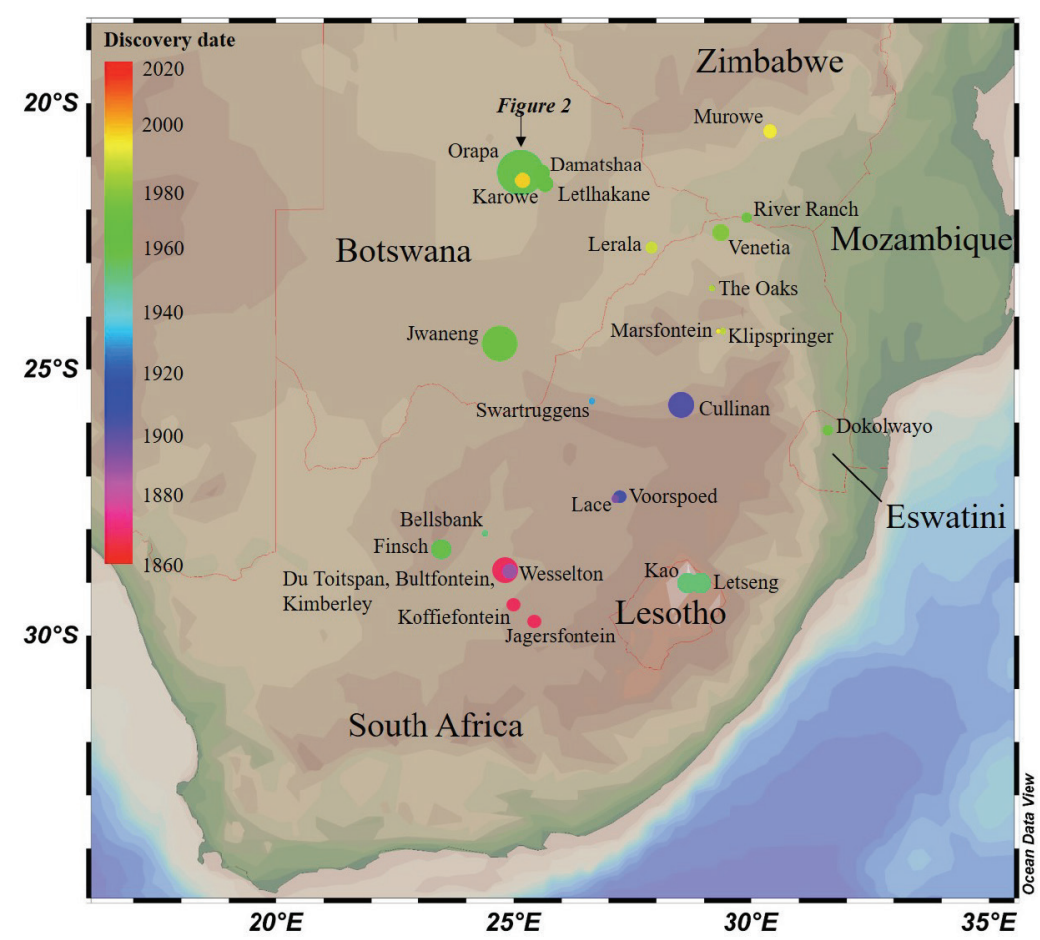

Figure 1-Distribution, size, and discovery date of selected southern African diamondiferous kimberlites. The location circles are scaled according to the original kimberlite pipe surface area and coloured according to the discovery date. All data extracted and redrawn from McKechnie (2019), and references listed therein

study evaluates the geological and financial data reported for 12 southern African kimberlite diamond mines, using a critical comparison between the economic Karowe deposit, hereafter referred to by its former name AK6 (Campbell and Jooste, 2017), and the sub-economic BK11 mineral occurrence as a useful point of departure. A key outcome of the work is the development of a novel economic filter which may be utilized as a geo-economic tool for early assessment of diamond projects, to ultimately improve future diamond mining opportunities in sub-Saharan Africa.

\section{Use of economic filters in mineral asset valuation}

Although less precise than full feasibility studies, simple economic filters (or cost models) have found extensive use as a tool for broadly discriminating between economic and noneconomic mineral assets (e.g., Long and Singer, 2001, and references therein). Much of this work has been pioneered by the US Bureau of Mines (Camm, 1991; Smith, 1992) and the US Geological Survey (Singer, Menzie, and Long, 1998; Long and Singer, 2001; Robinson and Menzie, 2014). The basic premise underpinning these works is that empirical data from existing mines can be used to predict operating costs and capital expenditure for yet-unmined mineral deposits (or, more correctly, mineral occurrences). This predicted data in turn can be used to model net present value (NPV) calculations to discern whether or not a mineral asset is likely to be economically viable under the current economic conditions. The results from these theoretical economic filters can then be plotted on a grade-tonnage graph to test whether the predictions of economic viability hold true against empirical data from known mines/deposits. This approach has been applied successfully to open-pit gold-silver deposits (Singer, Menzie, and Long, 1998), underground massive sulphide deposits (Singer, Menzie, and Long, 2000), and porphyry copper deposits (Robinson and Menzie, 2014).

\section{Economic filter development: A case study using AK6 and BK11 as examples}

Our approach towards developing a cost filter for southern African diamondiferous kimberlites differs fundamentally from the approach described in the preceding section. Instead of using predicted expenditure cash flows to model a theoretical NPV for an unknown deposit, we effectively 'reverse engineer' the process by modifying the input parameters for an NPV calculation of a known economic kimberlite deposit until this deposit becomes uneconomic. To limit the effects of external factors on the results (e.g., socio-political risks, differences in currency strength, labour costs, etc.), our study considers two spatially associated open-pit kimberlite deposits; AK6 (economic in 2017) and BK11 (subeconomic in 2017). It should be noted that this geographically constrained approach assumes broadly similar capital costs, operating cost structures, and fiscal regimes for any sub-Saharan kimberlite mining operation. It is recognized that there will always be local differences driven by scale, mining differences, processing differences, and other cost differences, but the goal of the filter is to provide a tool for initial assessment. The tool will also be valid only if statistically relevant sampling for diamond grade and average diamond value has been conducted.

\section{Geological background}

The AK6 and BK11 kimberlites are located in east-central Botswana and form part of the Orapa kimberlite field (Figure 2). The Orapa kimberlite field comprises 86 kimberlites that were emplaced between 111 and $85 \mathrm{Ma}$ (Preston et al., 2012). These kimberlites are found towards the north-western margin of the Kalahari Craton where a deep, stable, and relatively cool lithospheric keel provided ideal conditions for diamond formation and, ultimately, subsequent entrainment (e.g., Stachel et al., 2003; Deines and Harris, 2004). The kimberlites crosscut the Archean 


\section{A novel economic-filter for evaluating sub-Saharan diamondiferous kimberlites}

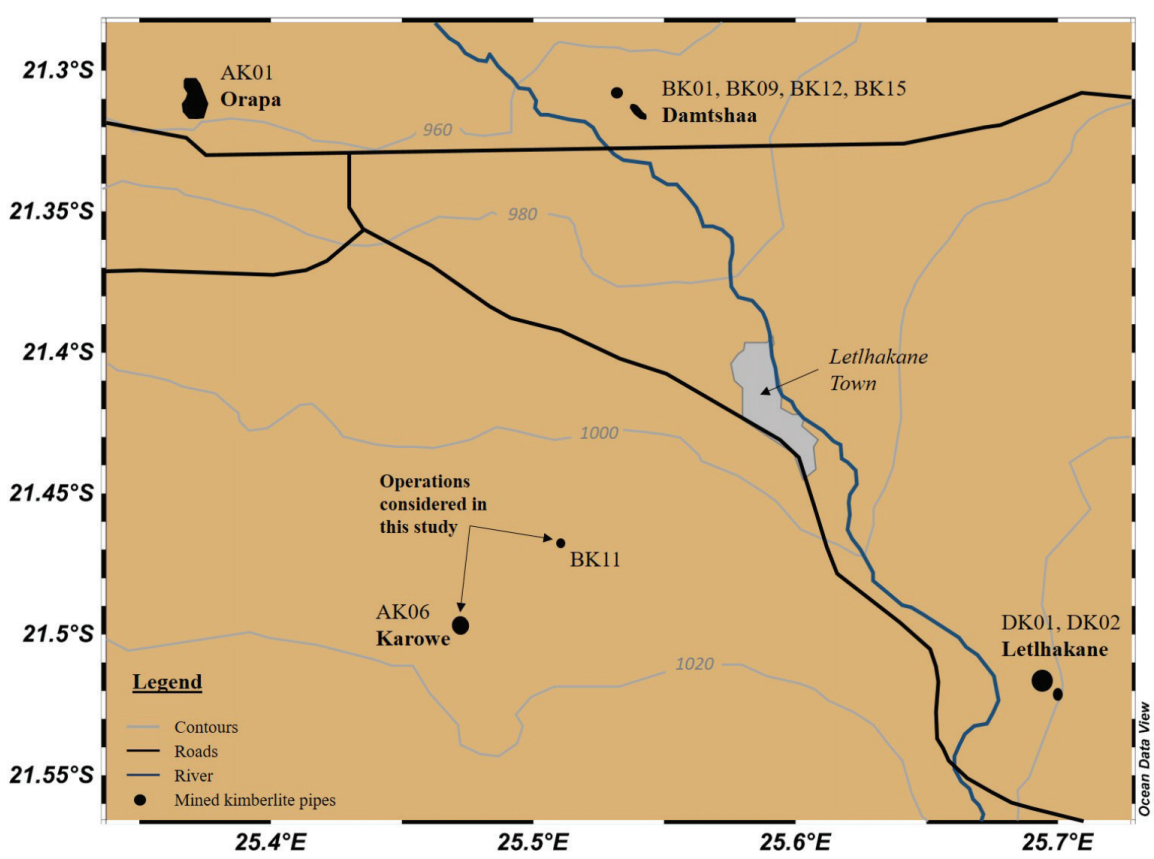

Figure 2-Kimberlite mining operations in the Orapa diamond field. Contours and approximate kimberlite pit sizes are redrawn from Google Earth imagery

basement lithologies and intrude into the 200-250 m thick Karoo Supergroup sediments and overlying basalt of the Stormberg Group (approx. $130 \mathrm{~m}$ thick). The upper host rocks units have been highly calcretized due to extended periods of weathering during the late Cenozoic (Lucara Diamond Corp., 2014), and are veneered by a thin layer of Quaternary-aged Kalahari sands.

The AK6 kimberlite comprises three distinct lobes that have been divided into 23 different facies assemblages (Lucara Diamond Corp., 2014). Current diamond production is focused on the South Lobe, which is relatively homogeneous in its facies distribution and hosts the majority of AK6's large and exceptional Type-II diamonds (Lucara Diamond Corp., 2014). In comparison, the BK11 kimberlite is a single, broad pipe that has been divided into nine different kimberlite facies, of which the fragmental upper crater facies (RVK-K1) is the most diamondiferous (Senlis Consultancy Limited, 2015). Mining of BK11 commenced in 2010, but ceased in 2012 on account of production not meeting forecast performance levels. Both pipes are endowed with Type-I and Type-IIa diamonds (Lucara Diamond Corp., 2014; Senlis Consultancy Limited, 2015).

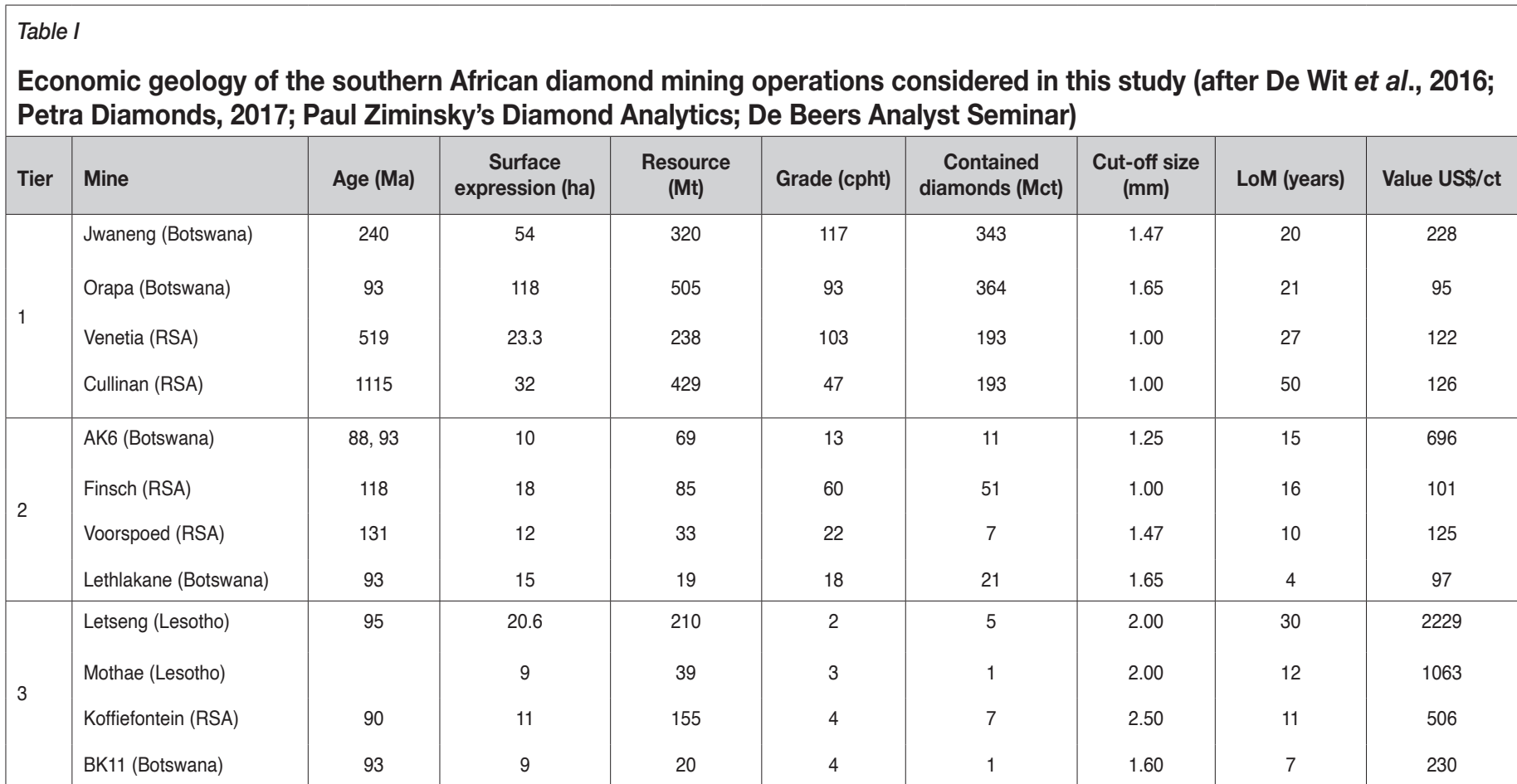




\section{A novel economic-filter for evaluating sub-Saharan diamondiferous kimberlites}

\section{Comparison with other southern African kimberlite diamond deposits}

Despite the geological similarities between AK6 and BK11, only the AK6 pipe is considered economic under the current market conditions. Table I reports pertinent data (grade, tonnage, average diamond value) for AK6, BK11, and a selection of other southern African kimberlite diamond mining operations. The data has been collected from the respective mines' 2016/2017 online published company reports and various other sources that are available in the public domain (e.g., De Wit et al., 2016; Petra Diamonds, 2017; Paul Zimnisky's Diamond Analytics; Anglo American plc, 2017). The selected non-alluvial diamond deposits have been classified, on the basis of million carats produced per annum (Mct/a), into the categories defined by De Wit et al. (2016); viz. tier 1: > $200 \mathrm{Mt}$ and 0.4 Mct/a; tier 2: > $0.4 \mathrm{Mct} / \mathrm{a}$; tier 3: 0.05-0.4 Mct/a. According to this classification scheme, the AK6 pipe is regarded as a tier 2 kimberlite diamond deposit, whereas BK11 is classified as tier 3. The latter deposit is further characterized by the lowest grade (measured in carats per hundred tons, cpht) and the smallest number of contained diamonds (measured in Mct). The reported diamond value (measured in US dollars per carat, however, is greater than the median of the diamond values (at 2016/2017 US dollar prices) reported for the other operations recorded in this data-set.

\section{An economic filter constrained using net present value (NPV) calculations}

Figure 3 plots the grade and value data from Table I for the kimberlite operations considered in this study. Although economic deposits can be discerned qualitatively or empirically from subeconomic or uneconomic deposits using such a two-parameter plot (e.g., Kjarsgaard 2007; Kjarsgaard, Januszczak, and Stiefenhofer, 2019), we employ a novel theoretical underpinning towards constraining the absolute position of the economic filter in gradevalue space (shown as the dashed line in Figure 3). This was achieved by considering a series of NPV calculations for the AK6 kimberlite; a pipe which is profitable (i.e., has a strongly positive NPV) under current economic conditions.
The basic or simplified financial modelling of the AK6 mineral asset was achieved using data updated from Lucara's NI 43101 Technical Report (2014) and the standard NPV calculation (Equation [1]). The discount rate used in this equation was set at $8 \%$, which is the standard for the diamond industry, and the calculation was run over 15 years (equal to the life of mine, LoM). Lucara's predicted revenues, cash flows, and capital expenditures for AK6 (Lucara, 2014) were updated for the LoM on the basis of operational statistics between 2013 and 2017, which saw a significant increase in the recovery of high-value Type-IIa diamonds.

$$
N P V=P V \times 1 /(1+i)^{n}
$$

where, $i=$ discount rate, $\mathrm{PV}=$ present value of net cash flow, and $n=$ number of years.

The revenue stream in this model includes two key variables, $v i z$. the diamond grade (how many carats of diamond are extracted per ton of kimberlite material mined) and the average diamond value (the average value of each extracted stone in US dollars per carat). A decrease in the value of either of these two variables will thus have a strong negative impact on the NPV calculated for the AK6 mineral asset. Based on these relationships, a more quantitative positioning of the economic filter was derived by simulating iterative $10 \%$ reductions in either the grade (cpht) or the value (US dollars per carat) until the financial model reflected a negative NPV, i.e., the operation was no longer deemed profitable (black dots in Figure 3). The resulting economic filter is therefore represented by an exponential regression line (Equation [2]) that has been 'forced' through these simulated points of negative NPV while still maintaining a 'best-fit' to the 12 empirical data-points representing the kimberlite operations considered in this study.

$$
y=1725.9 x^{-0.991}
$$

where $y$ is the average stone value per carat and $\mathrm{x}$ is the average grade of the mineral asset.

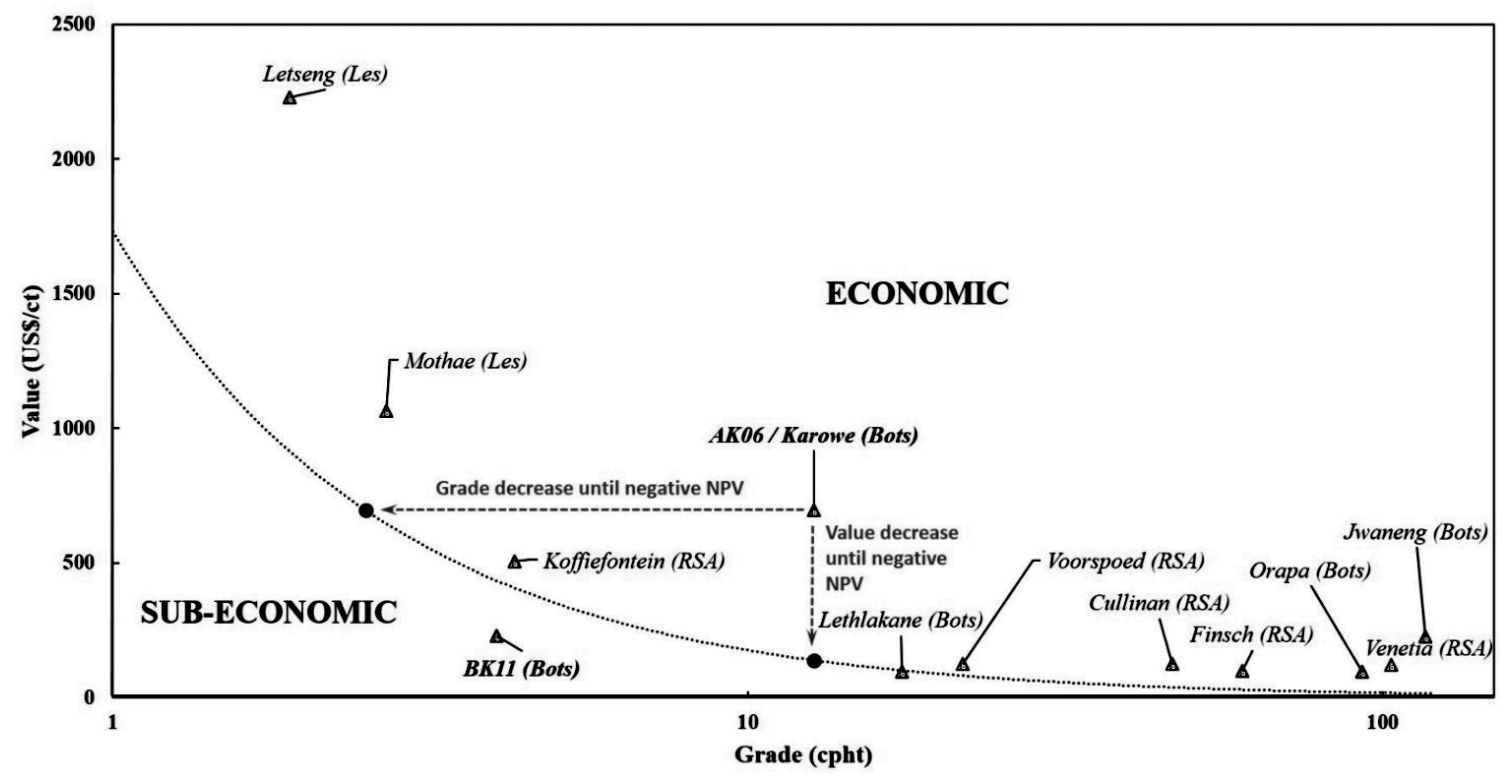

Figure 3-Novel economic filter for early assessment of kimberlite mining viability. Absolute position of the filter line is given by Equation [2] (see main text) and was constrained by iteratively decreasing the grade and value parameters of a simplied NPV calculation for the Karowe mining operation (AK6 kimberlite) until the NPV became negative (i.e. economically unfeasible) 


\section{A novel economic-filter for evaluating sub-Saharan diamondiferous kimberlites}

Mineral assets that fall above this line in grade-value space are deemed economic, whereas those that fall below this nominal cut-off will be either too low in grade (relative to the average diamond value) or have insufficient high-value stones (relative to grade), and are thus deemed sub-economic or uneconomic.

\section{Conclusion}

The successful exploitation of a diamond deposit depends on a diverse array of geological, mining, metallurgical, financial, political, and social parameters (Kjarsgaard, Januszczak, and Stiefenhofer, 2019). This high level of complexity poses a significant degree of difficulty when it comes to mineral asset valuation. To this end, several different approaches have been developed, viz. the Income Approach, the Cost Approach, and the Market Approach (SAMVAL, 2018), each with variable applicability to the different stages of mineral asset development (e.g., Davis, 2002; Njowa, Musingwini, and Clay, 2010). Our work introduces a novel methodology of developing an economic filter to assist with mineral asset valuation, specifically for use in comparing diamondiferous kimberlites discovered in southern Africa. Uniquely, the presented methodology combines elements of the established Market Approach (comparison among existing kimberlite operations) with elements of the Income Approach (NPV calculations for an existing operation used to constrain the absolute position of the economic filter in grade-value space). Such a combined approach effectively simplifies a preliminary economic evaluation into two parameters, while inherently accounting for operation-scale considerations (NPV constraints) under assumed broad regional similarities (regional socio-political conditions/ risk factors). We foresee that the developed economic filter will be useful in preliminary economic consideration of new, or known but yet unmined, kimberlite targets in sub-Saharan Africa; although cognisance must be taken of the fact that this model was developed from known production values between 2012 and 2017 (and diamond prices at the time). Crucially, application of the economic model to new deposits can be successful only if representative and statistically relevant sampling of that deposit has been undertaken to ensure an accurate knowledge its diamond grade and average diamond value. Finally, and importantly, we foresee that the novel approach holds high potential for adaptation and use in valuation of a range of commodity types (e.g., coal, Witwatersrand gold, etc.) for which the deposit style and the local socio-economic parameters (e.g., fiscal regimes and operating cost structures) are comparable.

\section{Acknowledgements}

The authors would like to thank the two anonymous reviewers and the handling editor for the insights that were provided and which helped to strengthen the manuscript. This work was made possible by the financial assistance from G. Leach, the first author's late father. This manuscript is dedicated to his memory. BvdH acknowledges the DSI-NRF Centre or Excellence for Integrated Mineral and Energy Resource Analysis (CIMERA) for additional funding that covers his running expenses.

\section{References}

Anglo American Plc. 2017. De Beers Analyst Seminar Presentation 2014. https:// www.angloamerican.com/ /media/Files/A/Anglo-American-Group/PLC/media/ presentations/2014pres/debeers-analyst-seminar-presentation-master-finalv. pdf [accessed 7 August 2017]

CAmm, T.W. 1991. Simplified cost models for prefeasibility mineral evaluations. Information Circular 9298. US Department of the Interior, Bureau of Mines. 35 pp.

CAmpBell, J.A. 2019. Financing diamond projects. Journal of the Southern African Institute of Mining and Metallurgy, vol.119, no. 2. pp. 139-147.
CampBell, J.A. and Jooste, V. 2017. The AK6 Kimberlite-Discovery through to production, learning the lessons of history. Proceedings of the Botswana Diamond Explorers Conference, April 2017. http://botswanadiamonds.co.uk/ media/res/the-ak6-kimberlite-layoutap.pdf

DAVEnPoRT, J. 2013. Digging Deep: A History of Mining in South Africa 1852-2002. Jonathan Ball, Johannesburg and Cape Town.

DAvIs, G.A. 2002. Economic methods of valuing mineral assets. Proceedings of the ASA/CICBV 5th Joint Business Valuation Conference, Orlando, Florida, 24-26 October. https://pdfs.semanticscholar. org/6234/3be8586206a0095f60ad10c821b9e07ed0ee.pdf

DeInES, P. and HarRis, J.W. 2004. New insights into the occurrence of 13C-depleted carbon in the mantle from two closely associated kimberlites: Letlhakane and Orapa, Botswana. Lithos, vol. 77, no. 1-4. pp. 125-142.

De Wit, M.C.J., Bhebe, Z., Davidson, J., Haggerty, S.E., Hundt, P., Jacob, J., Lynn, M., Marshall, T.R., Skinner, C., Smithson, K., Stiefenhofer, J., Roberts, M., Revitt, A, SpagGiari, R., and WARD, J., 2016. Overview of diamond resources in Africa. The Great Mineral Fields of Africa. Proceedings of the 35th International Geological Congress, Cape Town, South Africa. Wilson M.G.C. and Viljoen R.P. (eds) Episodes, vol. 39, no. 2. pp. 189-237.

Kimberley Process Statistics 2014 - 2016. https://kimberleyprocessstatistics.org/ public_statistics [accessed 15 August 2017].

KJARSGAaRd, B.A. 2007. Kimberlite diamond deposits. Mineral Deposits of Canada: A Synthesis of Major Deposit Types, District Metallogeny, the Evolution of Geological Provinces, and Exploration Methods. Goodfellow W.D. (ed.). Special Publication 5. Geological Association Canada, Mineral Deposits Division. pp. 245-272

KJARSGAard, B.A., JanuszczaK, N., and Stiefenhofer, J., 2019. Diamond exploration and resource evaluation of kimberlites. Elements, vol. 15, no. 6. pp. 411-416.

Linde, O., Martynov, A., Epstein, A., and Fischler, S., 2016. The global diamond industry 2016: The enduring allure of timeless gems. Bain \& Company and Antwerp Diamond Centre.

LoNG, K.R. and Singer, D.A. 2001. A simplified economic filter for open-pit mining and heap-leach recovery of copper in the United States. Report No. 01-218. US Geological Survey.

Lucara Diamond CoRp. 2014. Karowe Diamond Mine NI 43-101 Independent Technical Report (Amended). 154 pp.

McKeCHNIE, W.F., 2019. Diamond exploration and mining in southern Africa: Some thoughts on past, current and possible future trends. Journal of the Southern African Institute of Mining and Metallurgy, vol. 119, no. 2. pp. 123-131.

NJowa, G., MusingwinI, C., and CLAY, A. 2010. Development and implementation of a PGE mineral asset valuation curve. Proceedings of the Fourth International Platinum Conference: Platinum in Transition 'Boom or Bust, Sun City, South Africa, October 2010. Southern African Institute of Mining and Metallurgy, Johannesburg. pp. 353-359.

Petra Diamonds, 2017. Our Mines. https://www.petradiamonds.com/our-operations/ our-mines/cullinan/ [accessed 7 August 2017].

Preston, R.F., Perritt, S.H., Seller, M.H., and Wyatt, B.A. 2012. Lithospheric structure beneath the Cretaceous Orapa kimberlite field, Botswana: 4D lithosphere imaging using garnet indicator mineral chemistry. Proceedings of the 10th International Kimberlite Conference, Bangalore, India. Springer, New Delhi. Extended Abstracts, 10IKC-312. 5 pp. https://ikcabstracts.com/index. $\mathrm{php} / \mathrm{ikc/article/view/3796/3796}$

RoBinson JR, G.R. and MENzIE, W.D. 2014. Economic filters for evaluating porphyry copper deposit resource assessments using grade-tonnage deposit models, with examples from the US Geological Survey global mineral resource assessment: Report No. 2010-5090-H. US Geological Survey.

SAMVAL. 2018. South African Mineral Asset Valuation Committee (SAMVAL) Working Group. The South African Code for the Reporting of Mineral Asset Valuation (The SAMVAL Code), 2016 Edition. 1 October 2018. https://www. samcode.co.za/codes/category/8-reporting-codes?download=119:samval-code

Senlis Consultancy Limited. 2015. Preliminary Economic Assessment; BK11 Kimberlite Diamond Mine, National Instrument 43-101. Tango, Vancouver.

Singer, D.A., Menzie, W.D., and Long, K.R. 1998. A simplified economic filter for open-pit gold-silver mining in the United States. Report No. 98-207. US Geological Survey.

Singer, D.A., MenzIE, W.D., and Long, K.R. 2000. A simplified economic filter for underground mining of massive sulfide deposits. Report No. 2000-349. US Geological Survey.

Smith, R.C. 1992. PREVAL: Prefeasibility software program for evaluating mineral properties. Information Circular 9307. US Bureau of Mines. p. 35.

StAchel, T., Viljoen, K.S., McDade, P., and Harris, J.W., 2004. Diamondiferous lithospheric roots along the western margin of the Kalahari Craton - the peridotitic inclusion suite in diamonds from Orapa and Jwaneng. Contributions to Mineralogy and Petrology, vol. 147, no. 1. pp. 32-47.

Zimnisky, P. 2017. Chart of diamond production by nation. Paul Zimnisky Diamond Analytics. http://www.paulzimnisky.com/chart-of-diamond-production-bynation. 